\title{
How Coercive and Legitimate Power Relate to Different Conflict Management Styles: A Case Study of Birjand High Schools
}

\author{
Arash Riasi \\ Institute for Financial Services Analytics, University of Delaware \\ Apt. West 23, 97 Amstel Ave., Newark, DE, USA, 19711 \\ Tel: (302) 898-6249Ｅ-mail: riasi@udel.edu
}

Nasrin Asadzadeh

Office of Education, Isfahan, Iran

E-mail: asadzadeh47@yahoo.com

Received: Jan 26, 2016 Accepted: Feb. 5, 2016 Published: February 5, 2016

doi:10.5296/jse.v6i1.8946 URL: http://dx.doi.org/10.5296/jse.v6i1.8946

\begin{abstract}
This study investigates the relationship between two sources of organizational power (i.e., coercive and legitimate power) and five conflict management styles (i.e., avoiding, accommodating, competing, collaborating, and compromising style). Results of this study revealed that principals' coercive power has a positive relationship with avoiding and competing conflict management styles. Since these two conflict management styles both require low levels of cooperation, therefore it is fair to claim that higher degrees of coercive power facilitate the use of conflict management styles that require low levels of cooperation. It was also found that principals' legitimate power is positively related to accommodating and collaborating conflict management styles. Since both of these styles are associated with high levels of cooperation, therefore it is fair to claim that higher degrees of legitimate power will facilitate the use of conflict management styles requiring high levels of cooperation.
\end{abstract}

Keywords: Coercive Power, Legitimate Power, Conflict in Educational Organizations, Conflict Management Styles, Organizational Power 


\section{Introduction}

In every organization the manager should have some sort of power in order to be able to lead the organization toward its strategic goals. In an educational institution like a school, the school principal should have access to different sources of power to be able to control the employees and students efficiently. The strength of an educational system is an essential factor in determining the capacity of a country in achieving economic growth (Riasi, 2015a; Riasi \& Amiri Aghdaie, 2013; Riasi \& Pourmiri, 2015, 2016). A strong educational system contributes to economic development and enhanced social welfare (Riasi \& Asadzadeh, 2015). It is predicted that there will be a great demand for experts and professionals in different fields over the next few years in almost all developing countries around the globe (Amiri Aghdaie et al., 2012; Riasi, 2015b). The best way to respond to this demand is to create strong educational systems managed by professional and well-trained individuals. Studying different factors that can affect the efficiency of educational management is very important because it can help to design better strategies.

Educational management needs to be concerned with the ultimate goal of education (Bush, $1986 ; 1995 ; 1999 ; 2003)$. Many researchers have already studied the behavior of managers and how they make a difference in managing their organizations (Bass \& Avolio, 1994; Burns, 1978; Glatter \& Kydd, 2003; Payne, 1875; Senge, 1990; Simon, 1945; Taylor, 1895; Yukl, 1994). Studies focused on managing educational organizations follow a variety of methodologies (Heck \& Hallinger, 2005) in order to identify the characteristics of educational managers and to find how their behavior can affect the performance of their organization. In an educational environment, conflict management is part of the daily tasks of managers. Managing organizational conflict without having the power to do so is very difficult. The relationship between managerial sources of power and conflict management styles is a complicated relationship that needs to be further explored (Riasi \& Asadzadeh, 2015). The current study will try to focus on how coercive and legitimate power are related to different conflict management styles.

\section{Conceptual Development}

\subsection{Organizational Power}

According to Uhl-Bien and Carsten (2007), power can be defined as the sense of control and the perception that one has the ability to influence outcomes. Power and dependence are related concepts and higher levels of dependency can lead to higher degrees of power (Uhl-Bien \& Carsten, 2007). This relationship holds very strongly in educational organizations. According to French and Raven (1959) there are five different sources of organizational power, namely: coercive, referent, legitimate, expert and reward power (Table 1). These five sources of organizational power have been studied by many researchers and many of them tried to identify new sources (Carson et al., 1993; Finkelstein, 1992; Podsakoff $\&$ Schreisheim, 1985; Riasi \& Asadzadeh, 2015). In this section we will briefly introduce the concepts of coercive and legitimate power. These two sources of power were selected for this study, because they are the most important sources of power in educational organizations. 
Table 1. Sources of organizational power (French \& Raven, 1959)

\section{Sources of Power Definition}

Coercive power Power based on the perception that the manager can punish the employees if they do not conform to their manager's influence attempt.

Referent power Power based on the feeling of oneness of employees with their manager.

Legitimate power Power based on employees' belief that their manager has the legitimate right to manage the organization.

Expert power

Power based on the employees' perception of their managers' expertise within a given area.

Reward power Power based on the ability of the manager to reward the employees.

\subsubsection{Coercive Power}

Coercive power can be defined as the ability to influence others by using threats, punishments or sanctions; in an organizational setting this source of power can be used in order to control the employees and to ensure that their actions are congruent with organizational policies (Merchant, 2013). A manager has coercive power over an employee, when the employee anticipates possible punishment if he/she does not perform the required tasks. According to Hunt and Nevin (1974), coercive power is not similar to other sources of power because it involves potential punishment. For non-coercive sources of power (i.e., reward, referent, legitimate, and expert power), the employee willingly yields power to the manager, but when the manager has coercive power, the employee reluctantly yields power (Hunt \& Nevin, 1974). When the manager has coercive power, the degree of conformity of employees to their superior is dependent on the balance between punishment force and resisting force (French et al., 1960). If the employee believes that the private benefit from non-conformity is not enough to compensate for the possible punishment, he/she will definitely conform to the manager. Coercive power is one of the most important sources of organizational power for educational managers. In this study we will investigate the relationship between school principals' coercive power and their conflict management styles.

\subsubsection{Legitimate Power}

Legitimate power originates from internalized values in employees which force them to believe that their manager has the legitimate right to manage the firm by influencing the employees and the employees must do what their manager asks them to do (French \& Raven, 1959; Raven \& French 1958a). In other words, legitimate right is based on the employees' perception that their manager has a legitimate right to prescribe behavior for them and to influence them (Raven \& French, 1958b). Managers who have the legitimate power can influence their subordinates in different ways but this power is only limited to the scope of the formal authority of the managers (Lunenburg, 2012). Educational managers frequently use this source of power in order to influence their employees. The importance of legitimate 
power in educational organizations is particularly apparent at schools where school principals use this type of power to manage their organization. In this study we investigate the relationship between legitimate power of school principals and their conflict management styles.

\subsection{Conflict Management}

Many organizational tasks are performed by teams, and one of the important issues that a manager faces on a daily basis is the issue of conflict among team members. Conflict usually occurs in mixed-motive relationships in which employees have both competitive interests that cause the conflict to start and cooperative interests that incentivize them to negotiate in order to come to an agreement (Bacharach \& Lawler, 1981; Deutsch \& Krauss, 1962; Kochan \& Verma, 1983; Walton \& McKersie, 1965). Conflict is often characterized as a negative and destructive issue, but there is strong evidence that indicate conflict could have positive outcomes for the organizations if it is managed correctly (Riasi \& Asadzadeh, 2015; Tjosvold, 2006). If conflict is managed carefully then it can contribute to team effectiveness (Amason et al., 1995). Managing organizational conflict is an important issue for educational managers, particularly school principals. It is necessary for educational managers to learn different methods of managing conflict in order to control their organizations more efficiently (Riasi \& Asadzadeh, 2015). One of the most important aspects of conflict management that organizational managers should consider is the understanding of how negative effects of conflict could be minimized and how its positive effects could be maximized.

Conflict management requires various skills and there are disparate conflict management styles that could be used by managers. Blake and Mouton (1964) proposed a five-category model for classification of different methods for handling conflict modes. These five methods are forcing, withdrawing, smoothing, compromising, and problem solving. Another model which was proposed for handling interpersonal conflicts was the Thomas-Kilmann conflict mode instrument which introduced five different conflict management styles, namely competing, collaborating, compromising, avoiding, and accommodating (Thomas \& Kilmann, 1974; Kilmann \& Thomas, 1977). Table 2 provides a definition for each of these five conflict management styles. The five conflict management styles in Thomas-Kilmann conflict mode instrument are based on two dimensions: assertiveness (i.e., the degree to which a person attempts to satisfy his/her own concerns) and cooperation (i.e., the degree to which an individual attempts to satisfy the concerns of the other person who is involved in the conflict) (Kilmann \& Thomas, 1977; Thomas, 1976). In a previous study we found that there is a positive relationship between principals' reward power and accommodating conflict management style (Riasi \& Asadzadeh, 2015). The results of our previous study also revealed that there is no significant relationship between principals' reward power and the other four conflict management styles (Riasi \& Asadzadeh, 2015). The current study will focus on principals' coercive and legitimate power and their possible relationship with conflict management styles.

Table 2. Conflict management styles (Thomas \& Kilmann, 1974; Kilmann \& Thomas, 1977) 


\section{Conflict Management Styles Definition}

Accommodating style

Low assertiveness and high cooperation. The manager cooperates with the employees to a high extent and this cooperation might be against his/her managerial objectives.

Low assertiveness and low cooperation. The manager decides

Avoiding style to avoid the issue that caused the conflict. The manager neither peruses his/her own objectives nor cooperates with the employees to help them to reach their goals.

Collaborating style

High assertiveness and high cooperation. The manager and the employees collaborate with each other in order to satisfy the goals of both parties.

Competing style

High assertiveness and low cooperation. The manager is not willing to satisfy the objectives of the other party and only focuses on satisfying his/her own goals.

Moderate level of assertiveness and cooperation. Managers and

Compromising style employees follow their own objectives to some extent but at the same time they cooperate with each other moderately.

\subsection{Research Questions and Hypotheses}

This study intends to respond to two important questions. First, the study is trying to find out whether there is a significant relationship between principals' coercive power and their conflict management styles. Second, we will try to understand whether there is a relationship between principals' legitimate power and their conflict management styles. The results of this study will extend our knowledge about principals' ability to manage organizational conflict by using their sources of power. This study can be considered as an extension to our previous study on the relationship between principals' reward power and their conflict management styles. The following hypotheses will be tested in this study:

H1: Principals' coercive power is positively related to avoiding conflict management style.

H2: Principals' coercive power is positively related to accommodating conflict management style.

H3: Principals' coercive power is positively related to competing conflict management style.

H4: Principals' coercive power is positively related to compromising conflict management style.

H5: Principals' coercive power is negatively related to collaborating conflict management style.

H6: Principals' legitimate power is negatively related to avoiding conflict management style. 
H7: Principals' legitimate power is positively related to accommodating conflict management style.

H8: Principals' legitimate power is positively related to competing conflict management style.

H9: Principals' legitimate power is positively related to compromising conflict management style.

H10: Principals' legitimate power is positively related to collaborating conflict management style.

\section{Methodology}

\subsection{Sample}

The sample for this study included 49 high school principals who work in the city of Birjand. Birjand is a city located in eastern Iran and is the provincial capital of South Khorasan (Riasi, 2004). The city has a population of around 180000 and has 49 high schools which all of them are single-gender schools. Around $51 \%$ of the surveyed high school principals were male and $49 \%$ of them were female. Among the survey respondents, $4 \%$ of them were below 30 years old, 33\% were between 30 and 40 years old, 55\% were between 41 and 50 years old, and $8 \%$ were above 50 years old. The majority of the high school principals who participated in our study had more than 23 years of job experience (37\%); also 35\% of them had between 16 and 23 years of experience; $26 \%$ of the respondents had between 7 and 15 years of experience, and only $2 \%$ of principals had less than 7 years of experience.

\subsection{Measures and Measure Validation}

To measure the degree to which school principals' used each of the five conflict management styles and also in order to determine the principals' degree of coercive and legitimate power, we designed a survey with 40 items. The respondents were asked to rate the items in the survey on a five-point Likert scale ranging from "completely disagree" (1) to "completely agree" (5), unless otherwise indicated. After designing all the scales for measuring the five conflict management styles, coercive power, and legitimate power we performed a confirmatory factor analysis. The results of the factor analysis indicated that all of the scales were acceptable and the survey items designed for measuring each of the constructs did in fact loaded together. We also calculated the Cronbach's alphas (Cronbach, 1951) using IBM SPSS Statistics 23 to test the reliability of the scales. The Cronbach's alphas for all of the scales were above .76 which exceeds the recommended .70 threshold for acceptability of a scale (Nunnally \& Bernstein, 1994); indicating high reliability and internal consistency of the scales. In order to ensure that the data were normally distributed, a Shapiro-Wilk test of normality was performed (Shapiro \& Wilk, 1965). Shapiro-Wilk test of normality was used because the sample size was less than 50. The results of this test indicated that all of our constructs were normally distributed.

\section{Analysis and Results}




\section{Macrothink}

Before starting the data analysis, we calculated the average scores that survey respondents assigned to the items measuring each construct. In order to test the hypotheses we used bivariate correlations. Table 3 provides a summary of the results of the hypothesis tests. In this table, $r$ indicates the value of Pearson correlation coefficient, $p_{1}$ shows the $p$-value for the one-tailed significance test, and $\mathrm{p}_{2}$ indicates the $\mathrm{p}$-value for the two-tailed significance test. The correlation is considered to be significant at $95 \%$ confidence level if the p-value is less than .05 and if the p-value is less than .01 then we can conclude that the correlation is significant at the $99 \%$ confidence level. 
Table 3. Results of hypothesis tests

\begin{tabular}{|c|c|c|}
\hline Hypotheses & Results of Hypothesis Tests & Decision \\
\hline $\begin{array}{l}\text { H1: Principals' coercive power is } \\
\text { positively related to avoiding conflict } \\
\text { management style }\end{array}$ & $\begin{array}{l}\mathrm{r}=.373 \\
\mathrm{p}_{1}=.004 \\
\mathrm{p}_{2}=.008\end{array}$ & $\mathrm{H} 1$ is supported \\
\hline $\begin{array}{l}\mathrm{H} 2 \text { : Principals' coercive power is } \\
\text { positively related to accommodating } \\
\text { conflict management style }\end{array}$ & $\begin{array}{l}\mathrm{r}=.234 \\
\mathrm{p}_{1}=.053 \\
\mathrm{p}_{2}=.105\end{array}$ & $\mathrm{H} 2$ is not supported \\
\hline $\begin{array}{l}\text { H3: Principals' coercive power is } \\
\text { positively related to competing conflict } \\
\text { management style }\end{array}$ & $\begin{array}{l}\mathrm{r}=.305 \\
\mathrm{p}_{1}=.016 \\
\mathrm{p}_{2}=.033\end{array}$ & $\mathrm{H} 3$ is supported \\
\hline $\begin{array}{l}\text { H4: Principals' coercive power is } \\
\text { positively related to compromising } \\
\text { conflict management style }\end{array}$ & $\begin{array}{l}\mathrm{r}=.195 \\
\mathrm{p}_{1}=.090 \\
\mathrm{p}_{2}=.179\end{array}$ & H4 is not supported \\
\hline $\begin{array}{l}\text { H5: Principals' coercive power is } \\
\text { negatively related to collaborating } \\
\text { conflict management style }\end{array}$ & $\begin{array}{l}\mathrm{r}=-.171 \\
\mathrm{p}_{1}=.120 \\
\mathrm{p}_{2}=.239\end{array}$ & H5 is not supported \\
\hline $\begin{array}{l}\text { H6: Principals' legitimate power is } \\
\text { negatively related to avoiding conflict } \\
\text { management style }\end{array}$ & $\begin{array}{l}\mathrm{r}=-.202 \\
\mathrm{p}_{1}=.082 \\
\mathrm{p}_{2}=.164\end{array}$ & H6 is not supported \\
\hline $\begin{array}{l}\text { H7: Principals' legitimate power is } \\
\text { positively related to accommodating } \\
\text { conflict management style }\end{array}$ & $\begin{array}{l}\mathrm{r}=.324 \\
\mathrm{p}_{1}=.012 \\
\mathrm{p}_{2}=.023\end{array}$ & $\mathrm{H} 7$ is supported \\
\hline $\begin{array}{l}\text { H8: Principals' legitimate power is } \\
\text { positively related to competing conflict } \\
\text { management style }\end{array}$ & $\begin{array}{l}\mathrm{r}=.065 \\
\mathrm{p}_{1}=.330 \\
\mathrm{p}_{2}=.660\end{array}$ & H8 is not supported \\
\hline $\begin{array}{l}\text { H9: Principals' legitimate power is } \\
\text { positively related to compromising } \\
\text { conflict management style }\end{array}$ & $\begin{array}{l}\mathrm{r}=.067 \\
\mathrm{p}_{1}=.325 \\
\mathrm{p}_{2}=.650\end{array}$ & H9 is not supported \\
\hline $\begin{array}{l}\text { H10: Principals' legitimate power is } \\
\text { positively related to collaborating } \\
\text { conflict management style }\end{array}$ & $\begin{array}{l}\mathrm{r}=.328 \\
\mathrm{p}_{1}=.011 \\
\mathrm{p}_{2}=.021\end{array}$ & $\mathrm{H} 10$ is supported \\
\hline
\end{tabular}

Table 3 shows that the only hypotheses H1, H3, H7, and H10 were supported and the other six hypotheses were not supported. It was found that there is a significant positive relationship between principals' coercive power and avoiding conflict management style with $99 \%$ confidence. It was also found that principals' coercive power is positively related to competing conflict management style with $95 \%$ confidence. The results revealed that the principals' legitimate power is positively correlated with accommodating and collaborating conflict management styles with $95 \%$ confidence. 


\section{Discussion}

The results of this study complement our findings from a previous study on the relationship between principals' reward power and their conflict management styles (Riasi \& Asadzadeh, 2015). The only significant relationship which was found in that study was the positive relationship between principals' reward power and accommodating conflict management style (Riasi \& Asadzadeh, 2015). It is interesting that the current study also found a significant positive relationship between principals' legitimate power and their accommodating conflict management style. This finding suggests that reward power and legitimate power can be used together in order to facilitate the use of accommodating conflict management style. Using the accommodating style in order to manage organizational conflicts might be challenging because it requires high levels of cooperation and low levels of assertiveness and principals might be reluctant to use this conflict management style. Using the accommodating conflict management style is very effective when the employees' solution for resolving the conflict is much better than the manager's solution.

Based on our results, the accommodating style is mostly used by principals with high levels of reward power (Riasi \& Asadzadeh, 2015) and legitimate power. We also found a positive relationship between principals' legitimate power and collaborating conflict management style. Collaborating and accommodating styles are both associated with high levels of cooperation and since we found a positive relationship between legitimate power and both of these two conflict management styles we can conclude that higher levels of legitimate power could lead to higher levels of cooperation. In other words, managers who have higher levels of legitimate power are more willing to satisfy their employees' concerns compared to managers with lower levels of legitimate power.

Our results indicated that principals' coercive power is positively related to the avoiding conflict management style. Avoiding style is associated with low levels of cooperation and assertiveness and is useful when the issue that caused the conflict is trivial. Managers with higher levels of coercive power use the avoiding style more commonly and it seems that higher levels of coercive power facilitates the use of this conflict management style. We found that principals' coercive power is also positively related to competing conflict management style. The competing style is most effective when the manager has to make quick decisions and therefore only follows his/her own objectives without cooperating with the employees. The interesting result is that both avoiding and competing conflict management styles are associated with low levels of cooperation and since we found a positive relationship between coercive power and both of these two styles, we can conclude that higher levels of coercive power could lead to lower levels of cooperation. In other words, managers who have higher levels of coercive power are less willing to satisfy their employees' concerns compared to managers with lower levels of coercive power.

\section{Conclusions}

Results of this study indicated that principals' coercive power has a positive correlation with conflict management styles that require low levels of cooperation (i.e., avoiding and competing conflict management styles). On the other hand, it was found that principals' 
legitimate power is positively related to conflict management styles that require high levels of cooperation (i.e., accommodating and collaborating styles). Based on these findings we can conclude that managers should identify the sources of organizational power which are available to them and choose the appropriate conflict management style based on their available sources of power and their willingness to cooperate with employees in order to settle the organizational conflicts. This will help the managers to handle the organizational conflicts efficiently.

\section{References}

Amason, A. C., Thompson, K. R., Hochwarter, W. A., \& Harrison, A. W. (1995). Conflict: An important dimension in successful management teams. Organizational Dynamics, 24(2), 20-35. http://dx.doi.org/10.1016/0090-2616(95)90069-1

Amiri Aghdaie, S. F., Seidi, M., \& Riasi, A. (2012). Identifying the barriers to Iran's saffron export by using Porter's diamond model. International Journal of Marketing Studies, 4(5), 129-138. http://dx.doi.org/10.5539/ijms.v4n5p129

Bacharach, S.B. \& Lawler, E.J. (1981). Bargaining: power, tactics and outcomes. San Francisco, CA: Jossey-Bass.

Bass, B. \& Avolio, B. (1994). Improving Organizational Effectiveness through Transformational Leadership. Thousand Oaks, CA: Sage.

Blake, R. R. \& Mouton, J. S. (1964). The managerial grid. Houston, TX: Gulf Publishing.

Burns, J. (1978). Leadership. New York: Harper \& Row.

Bush, T. (1986). Theories of educational management. London: Harper \& Row.

Bush, T. (1995). Theories of educational management: Second edition. London: Paul Chapman.

Bush, T. (1999). Crisis or crossroads? The discipline of educational management in the late 1990s. Educational Management and Administration, 27(3), 239-252. http://dx.doi.org/10.1177/0263211X990273002

Bush, T. (2003). Theories of educational management: Third Edition. London: Sage.

Carson, P. P., Carson, K. D., \& Roe, C. W. (1993). Social power bases: A metaanalytic examination of interrelationships and outcomes. Journal of Applied Social Psychology, 23(14), 1150-1169. http://dx.doi.org/10.1111/j.1559-1816.1993.tb01026.x

Cronbach, L. J. (1951). Coefficient alpha and the internal structure of tests. Psychometrika, 16(3), 297-334. http://dx.doi.org/10.1007/BF02310555

Deutsch, M., \& Krauss, R. M. (1962). Studies of interpersonal bargaining. Journal of Conflict Resolution, 6(1), 52-76. http://dx.doi.org/10.1177/002200276200600107

Finkelstein, S. (1992). Power in top management teams: Dimensions, measurement, and validation. Academy of Management Journal, 35, 505-538. http://dx.doi.org/10.2307/256485 
French J. R. P., Morrison, W., \& Levinger, G. (1960). Coercive power and forces affecting conformity. The Journal of Abnormal and Social Psychology, 61(1), 93-101. http://dx.doi.org/10.1037/h0041522

French, J. R. P., \& Raven, B. H. (1959). "The Bases of Social Power", in Cartwright D. (Eds.), Studies in social power. Ann Arbor, MI: Institute for Social Research. 150-167.

Glatter, R., \& Kydd, L. (2003). "Best Practice" in educational leadership and management: Can we identify it and learn from it? Educational Management \& Administration, 31(3), 231-43. http://dx.doi.org/10.1177/0263211x03031003002

Heck, R. H., \& Hallinger, P. (2005). The Study of Educational Leadership and Management Where Does the Field Stand Today? Educational Management Administration \& Leadership, 33(2), 229-244. http://dx.doi.org/10.1177/1741143205051055

Hunt, S. D., \& Nevin, J. R. (1974). Power in a channel of distribution: sources and consequences. Journal of Marketing Research, 11(2), 186-193. http://dx.doi.org/10.2307/3150557

Kilmann, R. H., \& Thomas, K. W. (1977). Developing a forced-choice measure of conflict-handling behavior: The" MODE" instrument. Educational and Psychological Measurement, 37(2), 309-325. http://dx.doi.org/10.1177/001316447703700204

Kochan, T.A. \& Verma, A. (1983). "Negotiations in organizations: blending industrial relations and organizational behavior approaches", in Bazerman, M. \& Lewicki, R.J. (Eds.), Negotiating in Organizations. Beverly Hills, CA: Sage. 13-32.

Lunenburg, F. C. (2012). Power and leadership: an influence process. International journal of management, business, and administration, 15(1), 1-9.

Merchant, P. (2013). 5 Sources of Power in Organizations. Retrieved March 5, 2015, from http://smallbusiness.chron.com/5-sources-power-organizations-14467.html

Nunnally, J. C., \& Bernstein, I. H. (1994). Psychometric theory (3rd ed.). New York: McGraw-Hill.

Payne, W.H. (1875). Chapters on School Supervision. New York City, NY: Wilson, Hinkle \& Co.

Podsakoff, P. M., \& Schriesheim, C. A. (1985). Field studies of French and Raven's bases of power: Critique, reanalysis, and suggestions for future research. Psychological Bulletin, 97, 387-413. http://dx.doi.org/10.1037/0033-2909.97.3.387

Raven, B. H., \& French, J. R. P. (1958a). Group support, legitimate power, and social influence. Journal of Personality, 26(3), 400-409. http://dx.doi.org/10.1111/j.1467-6494.1958.tb01595.x

Raven, B. H., \& French, J. R. P. (1958b). Legitimate power, coercive power, and observability in social influence. Sociometry, 21(2), 83-97. http://dx.doi.org/10.2307/2785895 
Riasi, A. (2004). Introducing some of the most famous tourist attractions of Iran and the world, Mashhad: Sokhan Gostar Publication.

Riasi, A. (2015a). Barriers to international supply chain management in Iranian flower industry. Management Science Letters, 563-368. http://dx.doi.org/10.5267/j.msl.2015.2.005

Riasi, A. (2015b). Competitive advantages of shadow banking industry: An analysis using Porter diamond model. Business Management and Strategy, 6(2), 15-27. http://dx.doi.org/10.5296/bms.v6i2.8334

Riasi, A., \& Amiri Aghdaie, S. F. (2013). Effects of a hypothetical Iranian accession to the World Trade Organization on Iran's flower industry. Consilience: The Journal of Sustainable Development, 10(1), 99-110.

Riasi, A., \& Asadzadeh, N. (2015). The relationship between principals' reward power and their conflict management styles based on Thomas-Kilmann conflict mode instrument. Management Science Letters, 5(6), 611-618. http://dx.doi.org/10.5267/j.msl.2015.4.004

Riasi, A., \& Pourmiri, S. (2015). Effects of online marketing on Iranian ecotourism industry: Economic, sociological, and cultural aspects. Management Science Letters, 5(10), 915-926. http://dx.doi.org/10.5267/j.msl.2015.8.005

Riasi, A., \& Pourmiri, S. (2016). Examples of Unsustainable Tourism in Middle East. Environmental Management and Sustainable Development, 5(1), 69-85. http://dx.doi.org/10.5296/emsd.v5i1.8705

Senge, P. (1990). The Fifth Discipline: The Art and Practice of the Learning Organization. New York: Doubleday.

Shapiro, S. S., \& Wilk, M. B. (1965). An analysis of variance test for normality (complete samples). Biometrika, 52(3/4), 591-611. http://dx.doi.org/10.2307/2333709

Simon, H. (1945). Administrative Behavior. New York City, NY: Macmillan.

Taylor, F.W. (1895). A Piece-Rate System, Being a Step toward a Partial Solution of the Labor Problem, Transactions of the American Society of Mechanical Engineers, 16, 856-92.

Thomas, K. W. (1976). "Conflict and conflict management", in Dunnette, M. (Eds.), Handbook of industrial and organizational psychology. Chicago, IL: Rand-McNally. 889-935.

Thomas, K. W., \& Kilmann, R. H. (1974). The Thomas-Kilmann Conflict Mode Instrument. Mountain View, CA: CPP, Inc.

Tjosvold, D. (2006). Defining conflict and making choices about its management: Lighting the dark side of organizational life. International Journal of Conflict Management, 17(2), 87-95. http://dx.doi.org/10.1108/10444060610736585 


\section{Macrothink}

Journal of Studies in Education

ISSN 2162-6952 2016, Vol. 6, No. 1

Uhl-Bien, M., \& Carsten, M. (2007). Being ethical when the boss is not. Organizational Dynamics, 36(2), 187-201. http://dx.doi.org/10.1016/j.orgdyn.2007.03.006

Walton, R., \& McKersie, R.B. (1965). A behavioral theory of labor negotiations. New York, NY: McGraw-Hill.

Yukl, G. (1994). Leadership in Organizations. Englewood Cliffs, NJ: Prentice-Hall.

\section{Copyright Disclaimer}

Copyright for this article is retained by the author(s), with first publication rights granted to the journal.

This is an open-access article distributed under the terms and conditions of the Creative Commons Attribution license (http://creativecommons.org/licenses/by/3.0/). 